\title{
Abundant asexuality in tropical freshwater ostracodes
}

\author{
TOM J. LITTLE* \& PAUL D. N. HEBERT \\ Department of Zoology, University of Guelph, Guelph, Ontario, Canada N1G 2W1
}

\begin{abstract}
Comparisons of the distributional patterns of closely related sexual and asexual taxa have played an important role in efforts to deduce the evolutionary significance of sexual reproduction. However, the limited information now available concerning the incidence of asexual forms in the tropics remains an important gap in the data base. This study investigated the incidence of asexuality in Jamaican freshwater ostracodes, a group whose temperate zone members show frequent transitions to parthenogenesis. Analysis of gender ratios and genotypic diversity for 12 ostracode species from Jamaican ponds revealed only one species that reproduced sexually whereas the other taxa possessed genotypic characteristics typical of either diploid or polyploid apomictic parthenogens. The incidence of asexuality appears higher on Jamaica than on neighbouring mainland sites, a pattern which may be a consequence of the insularity and recent origin of its pond habitats.
\end{abstract}

Keywords: allozymes, breeding system, Jamaica, parthenogenesis, polyploidy.

\section{Introduction}

Despite the predominance of sexual reproduction in the animal kingdom its adaptive significance remains unclear (Michod \& Levin, 1988). Examining the origin, geographical distribution and fate of species which have made the transition to parthenogenesis has provided a useful approach to elucidating the factors maintaining sex (Lynch, 1984; Innes \& Hebert, 1988; Lively, 1992). Vandel (1928) first noted that parthenogens tend to have more northerly distributions than their sexual relatives. Recent models such as Bell's (1982) tangled bank hypothesis, Glesener \& Tilman's (1978) biotic complexity hypothesis and the reproductive assurance hypothesis (Lynch, 1984) make predictions about the specific habitat types where sexuals should predominate and each argues that parthenogens should be more common in arctic than in tropical habitats. Insects and many other invertebrate and plant groups do show a clear latitudinal trend in the incidence of parthenogenesis (Bell, 1982), but many of these parthenogens are polyploid. Several authors (Vandel, 1940; Soumalainen, 1962; Beaton \& Hebert, 1988 ) have suggested that selection for ploidy level as opposed to breeding system may create this latitudinal trend. Regardless if polyploidy is involved, tests of all these hypotheses are constrained by the lack of breeding system studies involving tropical species.

*Correspondence.
Studies of freshwater ostracode crustaceans from higher latitudes have shown that members of this group have frequently made the switch from sexuality to parthenogenesis (Bell, 1982; Havel \& Hebert, 1989; Havel et al., 1990a, b). In contrast to marine ostracodes, which are almost exclusively sexual, 41 per cent of freshwater species in temperate North America have abandoned sexuality (Bell, 1982). This shift is widespread, having occurred in 25 of 30 genera, with some species including both sexual and parthenogenetic populations (Chaplin, 1992). The regularity with which one encounters parthenogenesis in ostracodes makes them an ideal group in which to investigate the ecological correlates of breeding system shifts (Bell, 1982).

The mode of reproduction of ostracodes has historically been inferred from gender ratios, with parthenogenesis being assumed for all-female populations (Tressler, 1959). Recent genetic studies have confirmed the validity of this approach and have also established that some parthenogenetic ostracodes show exceptionally high levels of clonal diversity (Havel et al., 1990a, b; Turgeon, 1993). Although cytogenetic studies suggested that parthenogenetic ostracodes were primarily diploid (Bauer, 1940; Tetart, 1978), recent allozyme and genome size studies (Havel \& Hebert, 1989; Turgeon, 1993) indicate a relatively high incidence of polyploidy. While the forces mediating breeding system shifts in ostracodes remain unclear, parthenogenetic lineages often seem to arise from 
single sexual species rather than through interspecific hybridization as occurs in many other groups of organisms (Dawley, 1989). Most parthenogenetic ostracodes seem to be of recent origin (Turgeon \& Hebert, 1994) although the superfamily Darwinulacea may represent an ancient asexual lineage (Butlin \& Griffiths, 1993).

Genetic and breeding system analyses have so far been performed on ostracodes from arctic (Havel et al., $1990 \mathrm{a}, \mathrm{b})$ and temperate locations in North America (Havel \& Hebert, 1989; Turgeon, 1993) and Australia (Chaplin \& Ayre, 1989; Chaplin, 1992, 1993). This study examines the breeding systems and genetic characteristics of pond ostracodes from the subtropical island of Jamaica.

\section{Materials and methods}

\section{Collections and identifications}

Ostracodes were collected from 15 ponds at sites along the northern coast of Jamaica $\left(18^{\circ} \mathrm{N}, 77^{\circ} \mathrm{W}\right)$ in February 1991 and in April and May 1993. All samples were examined for the presence or absence of males and specimens were cryopreserved for later electrophoresis. Eleven of the 12 species present in collections were identified from the descriptions in Tressler (1959) and Broodbakker (1983c, 1984a). A single species of Cypridopsis, whose internal anatomy resembled that of $C$. vidua, lacked both the tumidity and pigmentation of the carapace typical of this species. However, as allozymic comparisons indicated considerable similarity between this species and clones of $C$. vidua from temperate North America, it was identified as Cypridopsis cf. vidua.

\section{Allozyme diversity}

Levels of allozyme variation were determined for each population using standard methods (Hebert \& Beaton, 1989). One to three populations of each species were screened for variation at 6-16 enzyme loci which included: aldehyde oxidase $(A O)$ (E.C. 1.2.3.1), amylase $(A M Y)$, arginine phosphokinase $(A P K)$ (E.C. 2.7.3.3), aspartate aminotransferase $(A A T)$ (E.C. 2.6.1.1), fumarate hydratase $(F U M)$ (E.C. 4.2.1.2), glyceraldehyde-3-phosphate dehydrogenase (G3PDH) (E.C. 1.2.1.12), hexokinase $(H E X)$ (E.C. 2.7.1.1), isocitrate dehydrogenase (IDH) (E.C. 1.1.1.42), lactate dehydrogenase $(L D H)$ (E.C. 1.1.1.27), malic enzyme $(M E)$ (E.C. 1.1.1.40), malic dehydrogenase $(M D H)$ (E.C. 1.1.1.37), mannose phosphate isomerase $(M P I)$ (E.C. 5.3.1.8), peptidase-A (leucyl-glycine), (PEP-A) (E.C. 3.4.1.13), phosphoglucomutase $(P G M)$ (E.C. 2.7.5.1), phosphoglucose isomerase (GPI) (E.C. 5.3.1.9) and xanthine dehydrogenase $(X D H)$ (E.C.
1.2.1.37). Following the initial screening, subsequent populations of a species were electrophoresed only for reliably scorable and polymorphic enzymes.

Alleles were designated by numbers corresponding to the anodal mobility of the enzyme, with higher numbers representing increasing migration. A locus was considered polymorphic if the frequency of the most common allele was $<0.96$. Heterozygosities were determined by direct counts for asexual species whereas for sexual species expected heterozygosities at polymorphic loci were calculated from allele frequencies. When sample sizes were 22 or greater, the concordance of observed genotype frequencies to Hardy-Weinberg (H.-W.) equilibrium was determined with a $\chi^{2}$ analysis. Heterozygote banding patterns were usually consistent with the known quaternary structure of each enzyme (Ward, 1977) but some individuals showed either unusual patterns of staining intensity or extra bands suggestive of polyploidy (Beaton \& Hebert, 1988; Havel et al., 1990a). When extra bands were detected, only the fastest and slowest bands were considered in estimating the allele frequencies used in H.-W. calculations. Since asexual organisms often show marked multilocus disequilibria (Hebert et al., 1988), populations polymorphic at three or more loci and/or possessing more than one clone, were analysed for nonrandom associations of multilocus genotypes by a $G$-test of independence (Sokal \& Rohlf, 1969). H.-W. disturbances and nonrandom associations of multilocus genotypes provide strong evidence of asexual reproduction. The fixation index $\left.\left(F=\left(H_{\mathrm{e}}-H_{\mathrm{o}}\right) / H_{\mathrm{e}}\right)\right)\left(\right.$ Hedrick, 1983), where $H_{\mathrm{o}}$ is the observed number of heterozygotes and $H_{\mathrm{e}}$ the number expected based on H.-W. predictions, was calculated for all polymorphic loci. Apomictic parthenogenesis is typically associated with all-female populations and heterozygote excesses (i.e. negative $F$ values) (Nevo, 1978; Bell, 1982) and the occurrence of both provides strong evidence for this mode of asexuality.

\section{Results}

Males were not detected for 11 of the 12 species collected (Table 1), suggesting that they reproduce by parthenogenesis whereas the other species possessed a female:male ratio of $1.06: 1$, which is not significantly different from $1: 1\left(\chi_{1}^{2}=0.05, P>0.8\right)$. Ten of the 12 species were collected in sufficient numbers to permit allozyme analysis but Chlamydotheca arcuata and Hemicypris barbadensi were too rare for electrophoretic examination.

Each of the nine parthenogenetic species that was examined for allozyme variation was represented by a 
small number of multilocus genotypes (Table 2). These species were, on average, polymorphic at 0.38 of their loci and showed an average heterozygosity of 0.21 (Table 1). The mean number of clones detected per pond was 1.3. Pooling the data from all habitats, the mean number of clones detected per species was 2.3.

Two species were represented by four or five clones. Cypridopsis cf. vidua, the most clonally diverse species, was present in two populations (Tables 2 and 3). Four of its five clones occurred in pond 2 (Table 3 ) and this population showed H.-W. disturbances at GPI $(P<0.05 ; \quad F=-0.62) \quad$ and $M P I \quad(P<0.001$; $F=-0.62)$, as well as significant nonrandom associations of genotypes $(G=25, P<0.005)$. The other population contained only one clone and showed highly significant $(P<0.0001 ; F=-1)$ H.-W. disturbances for both polymorphic loci. Clones 1,3 and 4 showed unbalanced heterozygotes for at least one locus (Table 2). Allozyme analysis of two populations of Cypretta turgida led to the detection of four clones (Tables 2 and 3), three of which showed the unbalanced banding patterns typical of polyploids. Both populations of $C$. turgida showed large $(P<0.0001 ; F=-1)$ H.-W. disturbances for at least two loci and the pond 8 population showed significant nonrandom associations of multilocus genotypes $(G=25, P<0.005)$.

Chlamydotheca unispinosa, the most ubiquitous species in this study, was represented by two clones (Tables 2 and 3). As clone 1 was homozygous at all loci, ponds containing only this clone (Table 3 ) could not be analysed for H.-W. conformity. Only pond 3 contained sufficient variation for such analysis and this population showed severe H.-W. disturbances $(P<0.0001 ; F=-1)$ at $P G M$. All heterozygote band- ing patterns were balanced, suggesting that this clone was diploid (Table 2).

Four other species (Cyprinotus incongruens, Strandesia longula, Stenocypris major and Tanycypris meridiana) were each represented by two clones (Tables 2 and 3 ). Both clones of $T$. meridiana and $S$. longula were probably diploid whereas one clone of $C$. incongruens and both clones of $S$. major demonstrated the unbalanced heterozygote banding patterns suggestive of polyploidy (Table 2). With the exception of $S$. major, which had a small sample size, and two populations of $T$. meridiana, all populations of these four species showed significant $(P<0.005)$ H.-W. disturbances because of heterozygote excess.

Two species (Cypris subglossa, Cypris decaryi) were found to be uniclonal. The sole population of $C$. subglossa was apparently diploid and was comprised of individuals heterozygous at both GPI and PGM (Tables 2 and 3). Cypris decaryi was relatively widespread, occurring in seven of 15 ponds (Tables 1 and 3 ) and the single, apparently diploid, clone of this species was heterozygous at four loci (Table 2).

Cypretta brevisaepta, the only species represented by both males and females, showed variation at four loci (Tables 1 and 4). Genotype frequencies at GPI, $A A T$ and $P E P$ were in agreement with $\mathrm{H}$.-W. expectations. The $M P I$ locus was sex-linked as males demonstrated a complete lack of heterozygosity whereas female genotypic frequencies fit H.-W. expectations (Table 4).

\section{Discussion}

This report documents the prevalence of asexuality in a tropical ostracode assemblage. Males were detected in

Table 1 Gender ratios and allozyme variability for 12 ostracode species from Jamaican ponds. Heterozygosities were estimated from allele frequencies for $C$. brevisaepta but by direct counts for all others

\begin{tabular}{llclc}
\hline Species & $\begin{array}{c}\text { Proportion } \\
\text { of females }(n)\end{array}$ & $\begin{array}{c}\text { No. of loci } \\
\text { scored }\end{array}$ & $\begin{array}{c}\text { Polymorphic } \\
\text { loci }\end{array}$ & Heterozygosity \\
\hline Cypridopsis cf. vidua & $1(76)$ & 6 & $G P I, M P I$ & 0.29 \\
Cypretta turgida & $1(100)$ & 8 & MPI, GPI, PGM & 0.29 \\
Chlamydotheca unispinosa & $1(200)$ & 9 & PGM & 0.04 \\
Cyprinotus incongruens & $1(30)$ & 5 & $G P I, M P I, P G M$ & 0.28 \\
Strandesia longula & $1(25)$ & 7 & $G P I, M P I$ & 0.14 \\
Stenocypris major & $1(45)$ & 8 & MPI MPI & 0.17 \\
Tanycypris meridiana & $1(44)$ & 7 & $G P I, M P I, A A T, A P K$ & 0.05 \\
Cypris decaryi & $1(100)$ & 11 & $G P I, P G M$ & 0.25 \\
Cypris subglossa & $1(24)$ & 8 & Not,$M P I$, AAT, PEP & 0.10 \\
Cypretta brevisaepta & $0.51(72)$ & - & Not electrophoresed & - \\
Hemicypris barbadensis & $1(6)$ & - & & - \\
Chlamydotheca arcuata & $1(2)$ & & & \\
\hline
\end{tabular}


Table 2 Multilocus genotypes, at polymorphic loci, detected for each of nine species of parthenogenetic ostracodes from Jamaica

\begin{tabular}{|c|c|c|c|c|c|c|c|}
\hline \multirow[b]{2}{*}{ Species } & \multirow{2}{*}{$\begin{array}{c}\text { Clone } \\
\text { identification } \\
\text { number }\end{array}$} & \multicolumn{6}{|c|}{ Multilocus genotype } \\
\hline & & $G P I$ & $P G M$ & $M P I$ & $A P K$ & $A A T$ & PEP \\
\hline \multirow[t]{5}{*}{ Cypridopsis cf. vidua } & 1 & $1 * 2$ & - & $1 * 2$ & - & - & - \\
\hline & 2 & 12 & - & 11 & - & - & - \\
\hline & 3 & $1 * 2$ & - & 11 & - & - & - \\
\hline & 4 & 11 & - & $1^{*} 2$ & - & - & - \\
\hline & 5 & 12 & - & 11 & - & - & - \\
\hline \multirow[t]{4}{*}{ Cypretta turgida } & 1 & $12^{*}$ & 33 & 236 & - & - & - \\
\hline & 2 & 22 & $1 * 23^{*}$ & $35^{*}$ & - & - & - \\
\hline & 3 & 23 & 44 & 14 & - & - & - \\
\hline & 4 & $2 * 3$ & 23 & 26 & - & - & - \\
\hline \multirow[t]{2}{*}{ Chlamydotheca unispinosa } & 1 & - & 22 & - & - & - & - \\
\hline & 2 & - & 12 & - & - & - & - \\
\hline \multirow[t]{2}{*}{ Cyprinotus incongruens } & 1 & 34 & 22 & 22 & - & - & 11 \\
\hline & 2 & 12 & $1 * 2$ & $1 * 2$ & - & - & 22 \\
\hline \multirow[t]{2}{*}{ Strandesia longula } & 1 & 11 & - & 12 & - & - & - \\
\hline & 2 & 12 & - & 22 & - & - & - \\
\hline \multirow[t]{2}{*}{ Stenocypris major } & 1 & $1 * 2$ & - & 22 & - & - & - \\
\hline & 2 & $1 * 2$ & - & 12 & - & - & - \\
\hline \multirow[t]{2}{*}{ Tanycypris meridiana } & 1 & - & - & 11 & - & - & - \\
\hline & 2 & - & - & 12 & - & - & - \\
\hline Cypris decaryi & 1 & 12 & - & 12 & 12 & 12 & - \\
\hline Cypris subglossa & 1 & 12 & 12 & - & - & - & - \\
\hline
\end{tabular}

*Represents the more intensely stained electromorph of an unbalanced heterozygous phenotype.

only one of the ten ostracode species found in abundance on Jamaica. The other rare species $(H$. barbadensis and C. arcuata) lacked males and the general absence of males in these species has been shown previously (Tressler, 1956; Broodbakker, 1983a). These results, along with the observed patterns of protein polymorphism, strongly suggest that the large majority of Jamaican pond ostracodes reproduce by apomictic parthenogenesis. In contrast to the all-female taxa, genotypic frequencies in the sole species ( $C$. brevisaepta) represented by both genders showed a general concordance with $\mathrm{H}$.-W. expectations.

Four of the nine parthenogenetic species possessed clones showing the unbalanced heterozygotes or threebanded patterns for monomeric loci typical of polyploid clones. Studies on cladocerans (Beaton \& Hebert, 1988) and plants (Bierzychudek, 1985) have suggested that the incidence of polyploid forms increases with latitude (Soumalainen, 1962). While it has been suggested that ostracodes show a similar pattern (Havel \& Hebert, 1989; Havel et al., 1990b), the current study does not support this assertion, as the incidence of polyploid clones on Jamaica is similar to that in temperate and arctic environments (Table 5).

Clonal diversty (Table 5) appears lower in Jamaican ostracodes $(\bar{x}=1.3)$ than in ostracodes from a range of sites in continental North America $(\bar{x}=4.1)$. Clonal variation within parthenogenetic ostracodes has been attributed to four sources: mutational input, automictic events, polyphyletic origins and asexual/sexual hybridization (Crease et al., 1989; Hebert et al., 1989; Turgeon, 1993). The importance of the latter two mechanisms is supported by the observation that parthenogens with sexual congeners are usually more clonally diverse than those from all-female genera (Havel et al., 1990b; Turgeon, 1993). The present study provides support for this hypothesis as both clonal diversity and the frequency of polyploid clones were, on average, twice as high in the Jamaican species (C. cf. vidua, C. turgida, C. unispinosa, C. incongruens and $S$. longula) with sexual congeners as in those lacking sexual relatives $(C$. decaryi, $C$. subglossa, $T$. 
Table 3 Clonal frequencies of parthenogenetic ostracodes from 15 Jamaican ponds

\begin{tabular}{|c|c|c|c|c|c|c|c|c|c|c|c|c|c|c|c|c|c|}
\hline \multirow[b]{2}{*}{ Species } & \multirow[b]{2}{*}{ Clone } & \multicolumn{15}{|c|}{ Pond } & \multirow{2}{*}{$\begin{array}{c}\text { Total } \\
(n)\end{array}$} \\
\hline & & 1 & 2 & 3 & 4 & 5 & 6 & 7 & 8 & 9 & 10 & 11 & 12 & 13 & 14 & 15 & \\
\hline Cypridopsis cf. vidua & $\begin{array}{l}1 \\
2 \\
3 \\
4 \\
5\end{array}$ & & $\begin{array}{r}15 \\
1 \\
2 \\
18\end{array}$ & & & & & & & & & 40 & & & & & $\begin{array}{r}15 \\
1 \\
2 \\
18 \\
40\end{array}$ \\
\hline Cypretta turgida & $\begin{array}{l}1 \\
2 \\
3 \\
4\end{array}$ & 100 & & & & & & & $\begin{array}{r}46 \\
9 \\
2\end{array}$ & & & 8 & & & & & $\begin{array}{r}100 \\
46 \\
9 \\
10\end{array}$ \\
\hline Chlamydotheca unispinosa & $\begin{array}{l}1 \\
2\end{array}$ & 17 & 36 & 73 & 60 & 45 & & 15 & & & & 14 & & & & & $\begin{array}{r}173 \\
87\end{array}$ \\
\hline Cyprinotus incongruens & $\begin{array}{l}1 \\
2\end{array}$ & & & & & & & & & & & & $\begin{array}{r}35 \\
8\end{array}$ & & & & $\begin{array}{r}35 \\
8\end{array}$ \\
\hline Strandesia longula & $\begin{array}{l}1 \\
2\end{array}$ & & & $\begin{array}{r}10 \\
8\end{array}$ & & & & & & & & & & & & & $\begin{array}{r}10 \\
8\end{array}$ \\
\hline Stenocypris major & $\begin{array}{l}1 \\
2\end{array}$ & & 16 & & & & & & & & & 22 & & 20 & & & $\begin{array}{l}36 \\
22\end{array}$ \\
\hline Tanycypris meridiana & $\begin{array}{l}1 \\
2\end{array}$ & & & & & & 24 & 10 & & & & & & & & 22 & $\begin{array}{l}34 \\
22\end{array}$ \\
\hline Cypris decaryi & 1 & 100 & 50 & 25 & & & & & & 48 & 37 & & & 24 & 24 & & 332 \\
\hline Cypris subglossa & 1 & & & & & & & & & & & & & & & 22 & 22 \\
\hline
\end{tabular}

Table 4 Allele frequencies at four loci for the sexually reproducing ostracode Cypretta brevisaepta

\begin{tabular}{|c|c|c|c|c|c|c|c|c|c|c|c|c|c|c|}
\hline & \multicolumn{3}{|c|}{$G P I$ allele } & \multicolumn{5}{|c|}{$M P I^{*}$ allele } & \multicolumn{3}{|c|}{$A A T$ allele } & \multicolumn{3}{|c|}{$P E P$ allele } \\
\hline & 1 & 2 & $n$ & 1 & 2 & 3 & 4 & $n$ & 1 & 2 & $n$ & 1 & 2 & $n$ \\
\hline Female & 0.98 & 0.02 & 52 & 0.04 & 0.96 & - & - & 47 & 0.17 & 0.83 & 36 & 0.87 & 0.13 & 46 \\
\hline Male & 0.94 & 0.06 & 50 & 0.04 & 0.90 & 0.06 & 0.02 & 49 & 0.21 & 0.79 & 50 & 0.84 & 0.16 & 48 \\
\hline
\end{tabular}

*All males were hemizygous at MPI.

meridiana and $S$. major) (Table 2). However, as most variation within a population arises from clonal immigration, rather than from in situ divergence, the low clonal diversity of Jamaican parthenogens should be examined in the context of colonization events and biogeography.

The prevalence of asexuals in specific habitat types has been linked to low biotic diversity (Glesener \& Tilman, 1978) or to reduced spatial heterogeneity (Bell, 1982) but these explanations make no predictions concerning the joint patterning of breeding systems and clonal diversity. Another hypothesis, linked to the greater colonization ability of asexual than sexual taxa
(Lynch, 1984), provides a more comprehensive explanation. Because parthenogens can initiate populations from a single propagule, habitats that are geographically isolated and of recent origin should show a high proportion of parthenogenetic species adapted to a fugitive lifestyle. Also, the clonal diversity of colonists should be low in recent habitats because few colonization events will have occurred.

As Jamaica was submerged until 15 million years ago (Arden, 1975), its biota has originated via transoceanic dispersal. The island has persisted sufficiently long for the evolution of endemic species flocks in many groups of terrestrial organisms (Liebherr, 1988) 
Table 5 Geographical distribution of breeding system, clonal diversity and polyploidy in freshwater ostracodes. The source column on the right refers to the information on polyploidy and clonal diversity only

\begin{tabular}{|c|c|c|c|c|c|c|c|}
\hline \multirow[b]{2}{*}{ Location } & \multicolumn{3}{|c|}{ No. of species in study } & \multirow{2}{*}{$\begin{array}{l}\text { No. of clones/ } \\
\text { species }\end{array}$} & \multirow{2}{*}{$\begin{array}{l}\text { No. of clones/ } \\
\text { pond }\end{array}$} & \multirow{2}{*}{$\begin{array}{l}\text { Frequency of } \\
\text { polyploids* }\end{array}$} & \multirow[b]{2}{*}{ Source } \\
\hline & Sexual & Asexual & Source & & & & \\
\hline High Arctic & 2 & 4 & $\mathrm{a}$ & 14 & 5 & 0.37 & a \\
\hline Low Arctic & 12 & 18 & b & 12.1 & 2.9 & 0.44 & b \\
\hline Temperate & 32 & 21 & $\mathrm{c}$ & 15 & 4.3 & 0.47 & $\mathrm{~g}$ \\
\hline Florida and Mexico & 25 & 26 & $\mathrm{~d}$ & - & - & - & - \\
\hline West Indies/all habitats & 10 & 14 & $\mathrm{e}$ & - & - & - & - \\
\hline West Indies/ponds and pools & 5 & 13 & $\mathrm{e}$ & - & - & - & - \\
\hline Jamaican ponds & 1 & 12 & $\mathrm{f}$ & 2.3 & 1.3 & 0.41 & $\mathrm{f}$ \\
\hline
\end{tabular}

a: Hebert (unpublished data) (as cited in b); b: Havel et al. (1990b); c: based on sex ratios, compiled from Furtos (1933); d: based on sex ratios compiled from Tressler (1959); e: based on sex ratios compiled from Broodbakker (1982, 1983a, 1983b, 1983c, 1984a, 1984b); f: current study; g: compiled from b and Turgeon (1993) and based on five species.

*Defined as the number of polyploid clones/total number of clones in the study.

but similar radiations are absent in freshwater ponds, whose fauna, particularly for ostracodes, is composed of species broadly distributed in the New World. This lack of endemics, as well as the prevalence of clonally impoverished parthenogens, may be a consequence of the loss of pond habitats in Jamaica during the recurrent bouts of aridity throughout the Pleistocene (Bonatti \& Gartner, 1973; Pegril \& Olsen, 1981). Certainly, even under current mesic conditions, freshwater ponds are both scarce and ephemeral on Jamaica. It is possible that most pond habitats, if not all, have originated since the end of the Wisconsinan glaciation.

Comparative information from continental sites with similar environmental conditions, such as Mexico and Florida, suggests a mugh higher incidence of sexual ostracodes than on Jamaica (Table 5). Sexual populations of at least two species $(C$. incongruens and $C$. unispinosa) predominate on nearby mainland sites but are absent on Jamaica. Prior surveys in the West Indies also suggest a greater prevalence of sexual ostracodes in deep water or cave habitats which are more likely than shallow ponds to have survived arid periods (Broodbakker, 1984b) (Table 5). For example, a sexual race of $S$. longula (described as $S$. botosaneanui by Broodbakker (1983c)) occurs in hypogean habitats in the West Indies. These geographical patterns and the close taxonomic association of asexuals and sexuals implies both a recent origin for the asexuals and an apparent linkage between habitat age and breeding systems. This latter association might be further analysed by examining the incidence of sexual reproduction in the ostracode fauna of more ancient habitats such as water reservoirs within bromeliad plants. Such habitats clearly represent ancient environments as evi- denced by the endemicity of both the bromeliad flora (Procter \& Read, 1972) and their associated invertebrate faunas (Liebherr, 1988; Diesel, 1992).

\section{Acknowledgements}

Jennie Chaplin made countless helpful comments on the manuscript and aided with collections. Magi Beaton, Terrie Finston and an anonymous reviewer also made useful comments on the manuscript. The Discovery Bay Marine Laboratory provided accommodation and lab space in Jamaica. Financial support was provided by a grant from the Natural Sciences and Engineering Research Council of Canada to P.D.N.H.

\section{References}

ARDEN, D. D., Jr. 1975. The geology of Jamaica and the Nicaraguan Rise. In: Nairm, A. E. M. and Stehli, F. G. (eds) The Ocean Basins and Margins, vol. 3, The Gulf of Mexico and the Caribbean, pp. 617-661. Plenum Press, New York.

BAUER, H. 1940. Uber die chromosomen der biesexuellen und der parthenogenetischen rasse des ostracodan Heterocypris incongruens. Ramd. Chromosoma, 1, 620-637. BELL, G. 1982. The Masterpiece of Nature. University of California Press, Berkeley, California.

BEATON, M. J. AND HEBERT, P. D. N. 1988. Geographic parthenogenesis and polyploidy in Daphnia pulex. Am. Nat., 132, 837-845.

BIERZYCHUDEK, P. 1985. Patterns in plant parthenogenesis. Experientia, 41, 1255-1264.

BONATTI, E. AND GARTNER, S. G. 1973. Caribbean climate during Pleistocene ice ages. Nature, 244, 563-565.

BRoodbakKer, N. w. 1982. The genus Heterocypris (Crustacea, Ostracoda) in the West Indies. Part I. Taxonomic characters. Bijdragen tot de Dierkunde, 52, 207-227. 
BroOdbakker, N. w. 1983a. The genus Hemicypris (Crustacea, Ostracoda) in the West Indies. Bijdragen tot de Dierkunde, 53, $135-157$.

BRoOdBAKKer, N. w. 1983b. The subfamily Candonidae (Crustacea, Ostracoda) in the West Indies. Bijdragen tot de Dierkunde, 53, 287-326.

BRoodbakker, N. W. 1983c. The genus Strandesia and other cypricercini (Crustacea, Ostracoda) in the West Indies. Part I. Taxonomy. Bijdragen tot de Dierkunde, 53, 327-368.

BROODBAKKer, N. w. 1984a. The genus Tanycypris (Crustacea, Ostracoda) in the West Indies. Bijdragen tot de Dierkunde, 54, 15-24.

Broodbakker, N. W. 1984b. The distribution and zoogeography of freshwater Ostracoda (Crustacea) in the West Indies, with emphasis on species inhabiting wells. Bijdragen tot de Dierkunde, 54, 25-50.

BUTLIN, R. K. AND GRIFFITHS, H. I. 1993. Ageing without sex. Nature, 364, 680.

CHAPLIN, J. A, 1992. Variation in the mode of reproduction among individuals of the ostracode Candonocypris novaezelandiae. Heredity, 68, 411-424.

CHAPLIN, J. A. 1993. The local displacement of a sexually reproducing ostracod by a conspecific parthenogen. Heredity, 71, 259-268.

CHAPLIN, J. A. AND AYRE, D. J. 1989. Genetic evidence of variation in the contributions of sexual and asexual reproduction to populations of the freshwater ostracod Candonocypris novaezelandiae. Freshwater Biol., 22, 275-284.

CREASE, T. J., STANTON, D. J. AND hebert, P. D. N. 1989. Polyphyletic origins of asexuality in Daphnia pulex. II. Mitochondrial-DNA variation. Evolution, 43, 1016-1026.

DAWLEY, R. M. 1989. An introduction to unisexual vertebrates. In: Dawley, R. M. and Bogart, J. P. (eds) Evolution and Ecology of Unisexual Vertebrates, pp. 1-18. Bulletin 466, New York State Museum, Albany.

DIESEL, R. 1992. Managing the offspring environment: brood care in the bromeliad crab, Metopaulias depressus. Behav. Ecol. Sociobiol., 30, 125-134.

FURTOS, C. 1933. The ostracoda of Ohio. Ohio Biological Survey, 5, 411-524.

GLESENER, R. R. AND TILMAN, D. 1978. Sexuality and the components of environmental uncertainty: clues from geographic parthenogenesis in terrestrial animals. Am. Nat., 122, 659-673.

HAVEL, J. E. AND HEBERT, P. D. N. 1989. Apomictic parthenogenesis and genotypic diversity in Cypridopsis vidua (Ostracoda, Cyprididae). Heredity, 62, 383-392.

HAVEL, J. E., HEBERT, P. D. N. AND DELORME, L. D. 1990a. Genetics of sexual Ostracoda from a low Arctic site. J. Evol. Biol., 3, 65-84.

HAVEL, J. E., HEBERT, P. D. N. AND DELORME, L. D. 1990b. Genotypic diversity of asexual Ostracoda from a low Arctic site. J. Evol. Biol., 3, 391-410.

HEBERT, P. D. N. AND BEATON, M. J. 1989. Methodologies for Allozyme Analysis using Cellulose Acetate Electrophoresis. Helena Laboratories, Beaumont, Texas.
HEBERT, P. D. N., BEATON, M. J., SCHWARTZ, S. S. AND STANTON, D. J. 1989. Polyphyletic origins of asexuality in Daphnia pulex. I. Breeding system variation and levels of clonal diversity. Evolution, 43, 1004-1015.

HEBERT, P. D. N., WARD, R. D. AND WEIDER, L. J. 1988. Clonal diversity patterns in Daphnia pulex, an asexual-sexual complex. Evolution, 42, 147-159.

HEDRICK, P. W. 1983. Genetics of Populations. Science Books International, Boston.

INNES, D. J. AND HEBERT, P. D. N. 1988. The origin and genetic basis of parthenogenesis in Daphnia pulex. Evolution, 42 , 1024-1035.

LIEBHERR, J. K. 1988. Biogeographic patterns of West Indian Platynus carabid beetles (Coleoptera). In: Liebherr, J. K. (ed.) Zoogeography of Caribbean Insects, pp. 121-152. Cornell University Press, Ithaca, N.Y.

LIEBHERR, J. K. 1988. Zoogeography of Caribbean Insects. Cornell University Press, Ithaca, N.Y.

LIVELY, C. M. 1992. Parthenogenesis in a freshwater snail: reproductive assurance versus parasitic release. Evolution, 46, 907-913.

LYNCH, M. 1984. Destabilizing hybridization, general purpose genotypes and geographic parthenogenesis. Q. Rev. Biol., 59, 257-290.

MICHOD, R. E. AND LEVIN, B. R. 1988. The Evolution of Sex: An Examination of Current Ideas. Sinauer Associates, Massachusetts.

NEVO, E. 1978. Genetic variation in natural populations: pattern and theory. Theor. Pop. Biol., 13, 121-127.

PEGRILL, G. K. AND OLSON, S. L. 1981. Zoogeography of West Indian vertebrates in relation to Pleistocene climatic cycles. Ann. Rev. Ecol. Syst., 12,75-98.

PROCTER, G. R. AND READ, R. w. 1972. Bromeliaceae. In: Adams, C. D. (ed.) Flowering Plants of Jamaica, pp. 41-53. University Press, Glasgow.

SOKAL, R. L. AND ROHLF, F. J. 1969. Biometry. W. H. Freeman, San Francisco.

SUOMALAINEN, E, 1962. Significance of parthenogenesis in the evolution of insects. Ann. Rev. Ent., 7, 349-365.

TETART, J. 1978. Les garnitures chromosomiques des Ostracoda d'eau deuce. Trav. Lab. Hydrobiol., 69, 113-140.

TRESSLER, W. L. 1956. Ostracoda from bromeliads in Jamaica and Florida. J. Wash. Acad. Sci., 43, 333-336.

TRESSLER, w. L. 1959. Ostracoda. In: Edmondson, W. T. (ed.) Freshwater Biology, pp. 657-734. Wiley, New York.

Turgeon, J. 1993. Genetic Diversity in Sexual and Asexual Members of Cyprinotus and Cypricercus (Ostracoda, Crustacea). M.Sc. Thesis, University of Guelph.

TURGEON, J. AND HEBERT, P. D. N. 1994. Evolutionary interactions between sexual and all l-female taxa of Cyprinotus (Ostracoda: Cyprididae). Evolution (in press).

VANDEL, A. 1928. La parthénogenèse géographique: contribution à l'étude biologique et cytologique de la parthénogenèse naturelle. Bull. Biol. Fr. Belg., 62, 164-281.

VANDEL, A. 1940. La parthénogenèse geographique. IV. Polyploidie et distribution géographique. Bull. Biol. Fr. Belg., 74, 94-100.

WARD, R. D. 1977. Relationship between enzyme heterozygosity and quaternary structure. Biochem. Genet., 15, 123-135. 